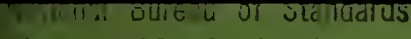

Lurary E-01 Admin. Bldg.

FEB 3 1969

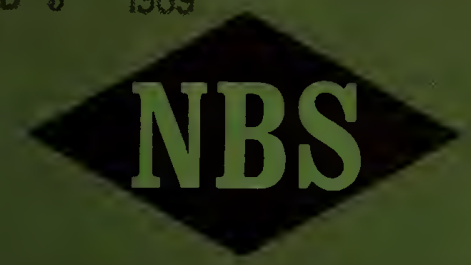

\section{Laboratory-Field Comparisons of Built-Up Roofing Membranes}

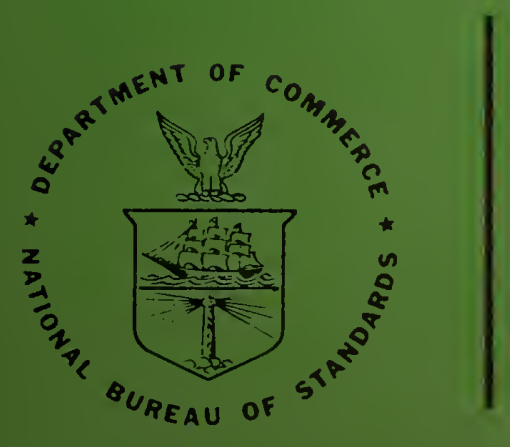

U.S. DEPARTMENT OF COMMERCE National Bureau of Standards 


\section{NATIONAL BUREAU OF STANDARDS}

The National Bureau of Standards ${ }^{1}$ was established by an act of Congress March 3, 1901. Today, in addition to serving as the Nation's central measurement laboratory, the Bureau is a principal focal point in the Federal Government for assuring maximum application of the physical and engineering sciences to the advancement of technology in industry and commerce. To this end the Bureau conducts research and provides central national services in three broad program areas and provides central national services in a fourth. These are: (1) basic measurements and standards, (2) materials measurements and standards, (3) technological measurements and standards, and (4) transfer of technology.

The Bureau comprises the Institute for Basic Standards, the Institute for Materials Research, the Institute for Applied Technology, and the Center for Radiation Research.

THE INSTITUTE FOR BASIC STANDARDS provides the central basis within the United States of a complete and consistent system of physical measurement, coordinates that system with the measurement systems of other nations, and furnishes essential services leading to accurate and uniform physical measurements throughout the Nation's scientific community, industry, and commerce. The Institute consists of an Office of Standard Reference Data and a group of divisions organized by the following areas of science and engineering:

Applied Mathematics-Electricity-Metrology_Mechanics-Heat_Atomic Phys-

ics-Cryogenics ${ }^{2}$-Radio Physics ${ }^{2}$-Radio Engineering ${ }^{2}$ - Astrophysics ${ }^{2}$-Time and Frequency. ${ }^{2}$

THE INSTITUTE FOR MATERIALS RESEARCH conducts materials research leading to methods, standards of measurement, and data needed by industry, commerce, educational institutions, and government. The Institute also provides advisory and research services to other government agencies. The Institute consists of an Office of Standard Reference Materials and a group of divisions organized by the following areas of materials research:

Analytical Chemistry-Polymers-Metallurgy — Inorganic Materials - Physical Chemistry.

THE INSTITUTE FOR APPLIED TECHNOLOGY provides for the creation of appropriate opportunities for the use and application of technology within the Federal Government and within the civilian sector of American industry. The primary functions of the Institute may be broadly classified as programs relating to technological measurements and standards and techniques for the transfer of technology. The Institute consists of a Clearinghouse for Scientific and Technical Information, ${ }^{3}$ a Center for Computer Sciences and Techıology, and a group of technical divisions and offices organized by the following fields of technology:

Building Research-Electronic Instrumentation - Technical Analysis - Product

Evaluation-Invention and Innovation-Weights and Measures - Engineering

Standards-Vehicle Systems Research.

THE CENTER FOR RADIATION RESEARCH engages in research, measurement, and application of radiation to the solution of Bureau mission problems and the problems of other agencies and institutions. The Center for Radiation Research consists of the following divisions:

Reactor Radiation-Linac Radiation-Applied Radiation-Nuclear Radiation.

1 Headyuarters and Laboratories at Gaithersburg. Maryland, unless otherwise noted; mailing address Washington, D. C. 20234.

2 Located at Boulder, Colorado 80302 .

${ }^{3}$ Located at 5285 Port Royal Road, Springfield, Virginia 22151. 
UNITED STATES DEPARTMENT OF COMMERCE

C. R. Smith, Secretary

NATIONAL BUREAU OF STANDARDS • A. V. Astin, Director

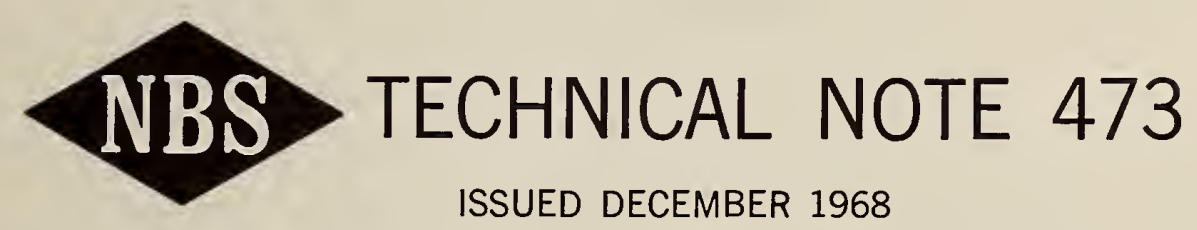

\title{
Laboratory-Field Comparisons of Built-Up Roofing Membranes
}

\author{
Thomas H. Boone, Leopold F. Skoda, \\ and William C. Cullen \\ Building Research Division \\ Institute for Applied Technology \\ National Bureau of Standards \\ Washington, D.C. 20234
}

NBS Technical Notes are designed to supplement the Bureau's regular publications program. They provide a means for making available scientific data that are of transient or limited interest. Technical Notes may be listed or referred to in the open literature.

For sale by the Superintendent of Documents, Government Printing Office Washington, D.C., 20402 - Price 25 cents 
CONTENTS

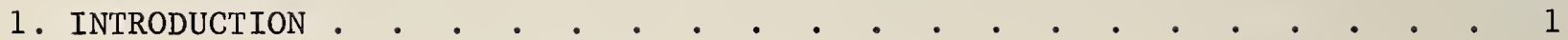

1.1. Historical Background . . . . . . . . . . . . . . . 2

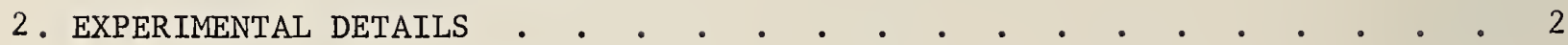

2.1. Samples Preparation . . . . . . . . . . . . . . . 2

2.1.1. Field Samples . . . . . . . . . . . . . . 2

2.1.2. Laboratory Samples . . . . . . . . . . . 3

2.2. Test Specimen Preparation . . . . . . . . . . . . . . 3

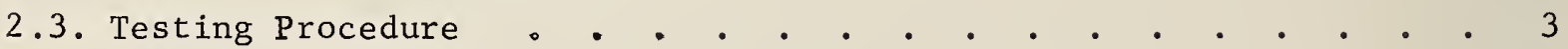

3. RESULTS • • • • • • • • • • • • • • • • • • • •

3.1. Discussion of Results . . . . • . • . . . . . . . . 4

4. CONCLUSIONS AND RECOMMENDATIONS

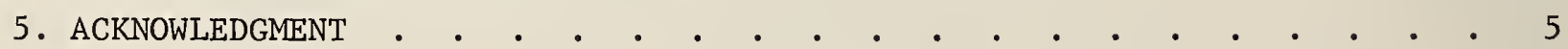

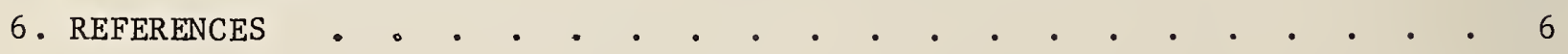


Thomas H. Boone, Leopold F. Skoda and William C. Cullen

The values of breaking load, elongation and thermal expansion of nine bituminous built-up membranes prepared by roofing contractors under field conditions and by technicians in the laboratory were measured at subfreezing temperatures. The data indicated that the field-prepared specimens agreed favorably with laboratoryprepared specimens, although the samples from the field frequently reflected higher values for thermal-shock resistance than did their laboratory-prepared counterparts. The higher values were attributed to the smaller amounts of bitumen used between the plies of the field specimens. The results appeared to support the validity of the application of the "strength-thickness rule" to bituminous built-up membranes.

KEY WORDS: Bituminous adhesive; bituminous built-up membranes; engineering properties; laboratory-field comparison; strength-thickness.

\section{INTRODUCTION}

Comparison of the results of tests of laboratory-prepared and fieldprepared specimens is of primary interest to both the research technician and users of materials in the building industry. When a new laboratory developed concept, such as "Thermal-Shock Resistance Factor,"Il is proposed, extensive testing of laboratory-prepared and field-prepared samples is necessary to determine the validity of the concept. In this connection a study to compare the values of the thermal-shock resistance factors of field-prepared and laboratory-prepared samples of built-up roofing systems was initiated. The program was conducted by the Building Research Division of the National Bureau of Standards in cooperation with the Midwest Roofing Contractors Association. Samples of nine built-up roof systems were prepared at a job site in Kansas City, Missouri. Portions of the materials used in the preparation of the samples in the field were furnished to the National Bureau of Standards laboratories in Gaithersburg, Maryland. Samples were prepared using these materials under controlled conditions by the National Bureau of Standards personne1. The specimens were tested to determine the engineering properties from which the thermal-shock resistance factors were calculated.

1/ TSRF $=\frac{\text { Breaking Load }}{\text { Elongation Modulus X Coeff. of Therm. Expansion }}$ 


\subsection{Historical Background}

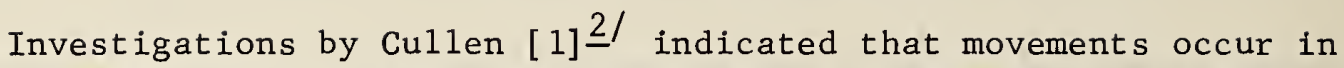
bituminous built-up roofing under temperature changes and he suggested that the stresses which result are contributing factors in tension splitting. He proposed the utilization of a thermal-shock resistance factor, calculated from engineering properties of the membrane, to predict the ability of the membrane to withstand the forces induced by temperature change [2] .

Cullen and Boone reported the values of the engineering properties [3] of laboratory-prepared and field-obtained bituminous built-up membranes and related tension splits to climate, thermal characteristics of the substrate, orientation of the reinforcing felt, and the composition of the built-up membrane. A comparison of results obtained between the laboratory-prepared specimens and specimens obtained from built-up roofing systems of known inservice behavior, indicated that the higher the value for the thermal-shock resistance factor, the more resistant the membrane was to tension splitting due to thermally induced forces.

The purpose of this investigation was to compare the values of the engineering properties and, hence, the thermal-shock resistance factor of roofing specimens prepared under closely controlled laboratory conditions by technical personnel with those constructed by roofers in accordance with accepted roofing practices under job-site conditions.

\section{EXPERIMENTAL DETAILS}

\subsection{Sample Preparation}

\subsubsection{Field Samples}

A roofing crew, under the supervision of Mr. Paul Morris, prepared the field samples. A member of the NBS staff observed the sample preparation. The asphalt and the roofing felts were obtained either from the job-site or from local warehouses. The asphalt had a softening point of $190^{\circ} \mathrm{F}\left(88^{\circ} \mathrm{C}\right)$. The field samples were prepared out-of-doors on a warm day in August, 1967 and are described in Table 1 . Specimens of felt were taken from the same rolls for shipment to the NBS laboratory for use in the preparation of laboratory samples. A sample of the asphalt was also shipped to the NBS.

A piece of roofing felt approximately 3 X 10 feet ( 1 X $3 \mathrm{~m}$ ) was placed on a smooth insulation board that had been coated with lime dust, as shown in Figure 1. The purpose of the lime dust was to prevent the samples from adhering to the insulation board. Molten asphalt at a kettle temperature of 425 to $450^{\circ} \mathrm{F}\left(218\right.$ to $\left.232^{\circ} \mathrm{C}\right)$ was mopped onto the felt, as shown in Figure 2. A second layer of felt was applied to the hot asphalt. Successive

2/ Numerals in brackets indicate the literature references at the end of this paper.

3/ Due to heat loss during transport, kettle temperatures are considerably higher than mopping temperatures. 
moppings of asphalt and layers of felt were applied until the required number of plies was completed. When the final coating of asphalt was sufficiently cool, the entire assembly was turned over and the bottom felt was coated with asphalt. Cut-outs approximately $2 \times 2$ feet $(.6 \times .6 \mathrm{~m})$ in size were taken from areas near the center of each assembly, as shown in Figure 3. The cut-outs were sent to the National Bureau of Standards together with the samples of felts and asphalt.

\subsubsection{Laboratory Samples}

The laboratory-prepared samples were made to simulate the field samples as closely as possible. The asphalt was heated in a thermostatically controlled electrically heated container. The asphalt was heated to about $300^{\circ} \mathrm{F}$ $\left(149^{\circ} \mathrm{C}\right)$ and stirred to insure uniform heating. The hot asphalt was applied between two $1 \mathrm{X} 1$ foot $(.3 \mathrm{X} .3 \mathrm{~m})$ pieces of felt which were then placed in a hydraulic press using spacers to control the thickness of the asphalt adhesive. This process was repeated with appropriate sized spacers to produce the desired number of plies. The top and bottom surfaces were coated with asphalt using the hydraulic press with spacers to control thickness.

\subsection{Test Specimen Preparation}

The samples were chilled to about $32^{\circ} \mathrm{F}\left(0^{\circ} \mathrm{C}\right)$ and dumbbell-shaped specimens as shown in Figure 4 were cut. Five specimens were cut in each direction (longitudinal and transverse to felt machine direction) to provide triplicate determinations of load-strain data and duplicate determinations for thermal expansion measurement.

\subsection{Testing Procedure}

The load-strain properties of the specimens were determined at $0^{\circ} \mathrm{F}$ $\left(-17.8^{\circ} \mathrm{C}\right)$ using a universal testing machine equipped with a temperature controlled chamber. Unit strain calculations were based on measured total elongation between the jaws of the testing machine which was 4.5 in. $(11.4 \mathrm{~cm})$. A straining rate of 0.05 in. $(.13 \mathrm{~cm})$ per minute $(1.1 \%$ per minute) was used in each determination.

For thermal expansion measurements the dumbbell-shaped specimens were fitted with gage points to receive a 5 in. $(12.7 \mathrm{~cm})$ Whittemore gage. The specimens were placed in a conditioning chamber and initial length measurements made at a temperature of $30^{\circ} \mathrm{F}\left(-1.1^{\circ} \mathrm{C}\right)$. The chamber temperature was lowered to $-30^{\circ} \mathrm{F}\left(-34.4^{\circ} \mathrm{C}\right)$ and measurements were again made. Thermal expansion was calculated from the change in length due to this $60^{\circ} \mathrm{F}\left(33.3^{\circ} \mathrm{C}\right)$ change in temperature.

The physical properties of the built-up membranes are listed in Table 1. The average sample thickness was measured with a micrometer caliper. The between-ply thickness was measured on a tool maker's microscope that has a movable stage driven by a micrometer screw. The between-ply spreading rates were calculated from the thickness measurements using a value of one for specific gravity of the asphalt.

$4 /$ This temperature approximates the mopping temperature attained in the field. 
Figure 5 is a typical tensile test load elongation curve illustrating the determinations of elongation modulus and breaking load.

Figures 6 and 7 show comparisons of field prepared and laboratory prepared samples with regard to strength and elongation properties. The crosshatched areas denote the upper and lower $95 \%$ confidence 1 imits of the average. There is no evidence of a significant difference between laboratory-prepared and field-prepared specimens for either property. Thickness measurements of samples indicated that less asphalt was used in the field specimens than in those prepared in the laboratory. This difference in sample thickness may have contributed to the observed trend in results. The tensile strength difference between longitudinal and transverse directions of the felt in the samples was as expected. The results indicate that the elongation property was generally unaffected by felt direction.

A comparison of the values of thermal-shock resistance factors of laboratory specimens and field specimens (Table 2) indicates that the field specimens generally produced higher values than did the laboratory specimens. These differences are reflected by the values of the physical properties.

\subsection{Discussion of Results}

The program was designed to compare the values of some physical properties [breaking load, elongation, thermal expansion] of several types of built-up roof membranes prepared both under field conditions and in the laboratory. To our knowledge, this is the first time that such a comparison has been made. The field specimens were prepared in accordance with good roofing practices by experienced roofers under the supervision of trained personnel. During application, an attempt was made to prepare specimens to meet the requirements of accepted roofing specifications, i.e., with an application of the mopping asphalt at a spreading rate from 20 to 25 pounds per 100 square feet ( 1 to $1.2 \mathrm{~kg} / \mathrm{m}^{2}$ ) between the plies of felt. The laboratory specimens were prepared by experienced research technicians under closely controlled conditions. The asphalt adhesive was applied at about 25 pounds per 100 square feet $\left(1.2 \mathrm{~kg} / \mathrm{m}^{2}\right)$. The physical properties of each set of specimens were measured under laboratory conditions. Under these circumstances, one would generally assume that the higher values would be obtained for the strength properties of the specimens prepared in the laboratory. The results, however, did not support this assumption. In fact, they showed that the field-prepared specimens consistently gave the higher values for the breaking load. On the other hand, lower values were obtained for thermal expansion while the values for elongation properties appeared to remain approximately the same for each type of specimen. Consequently, the values for the thermal-shock resistance factor, which were calculated from physical properties, were higher for the field specimens. This would indicate that the field-prepared specimens would have the higher resistance to tension splitting due to rapid temperature change. 
The question now arises as to how the results of the laboratory tests can be translated into information which can be readily used in field practice.

Strength-deformation characteristics of adhesive-adherend systems are affected by the thickness of the adhesive layer. The "strength-thickness" rule indicates that the strength of the adhesive-adherend system increases as the thickness of the film of the adhesive decreases. In a solid-asphaltsolid system subjected to tensile stresses, the validity of the strengththickness rule has been confirmed by a number of investigators [4]. The results of these tests also seem to support the "strength-thickness" rule. The test results of this program in terms of field practice indicate what appears to be a very significant finding, i.e. the physical properties improve as the thickness of the asphalt adhesive decreases. Assuming the results obtained in this series of tests are valid, this information could produce a major impact on currently promulgated roofing specifications and application techniques which in turn could ultimately affect the performance of built-up roofing in service. A comparison of the thickness measurements between laboratory and field specimens indicated that the majority of the currently promulgated roofing specifications may not reflect the current roofing practices in respect to rates of application of asphalt adhesive. The results also indicated that the optimum amount of bitumen for betweenthe-ply moppings may be somewhat less than is currently called for in most roofing specifications.

\section{CONCLUSIONS AND RECOMMENDATIONS}

Generally, the data reported in this paper indicate that field prepared specimens agree with laboratory prepared specimens. More specifically, the results frequently reflected higher values for the thermal-shock resistance factor for field applied specimens. This may be due, in part, to the differences in the adhesive thickness observed between laboratory and field specimens.

We would not recommend, at this time, that changes be made in specifications or in roof application techniques based on the data reported herein since it is preliminary in nature. However, we do recommend that additional research be conducted to study the applicability of the "strength-thickness" rule to bitumenous built-up roofing membranes.

\section{ACKNOWLEDGMENT}

The authors acknowledge with grateful appreciation the excellent cooperation of the Midwest Roofing Contractors Association including the financial support for the field portion of the program. Further, the assistance of Mr. P. L. Morris, Vice-President, Sellers and Marquis Roofing Company is worthy of special mention. 


\section{REFERENCES}

[1] W. C. Cullen, Effects of Thermal Shrinkage on Built-Up Roofing, NBS Monograph No. 89 (1965).

[2] W. C. Cullen, Solar Heating, Radiative Cooling and Thermal Movement Their Effects on Built-Up Roofing, NBS Technical Note 231 (December 1963).

[3] W. C. Cullen, T. H. Boone, Thermal-Shock Resistance for Built-Up Membranes, NBS Building Science Series No. 9 (August 1967).

[4] K. Majidzadeh, M. Herrin, Strength-Thickness Relations of Solid-AsphaltSolid Systems, ASTM Special Technical Publication No. 409 (1966).

[5] P. M. Jones, Recent Research on Bituminous Materials, ASTM Specia1 Technical Publication No. 347 (1963). 
Table 1. Physical Properties of Built-Up Roofing Membranes

\begin{tabular}{|c|c|c|c|c|c|c|}
\hline \multirow[b]{2}{*}{$\begin{array}{l}\text { Sample } \\
\text { No.․․ }\end{array}$} & \multicolumn{2}{|r|}{ Membrane } & \multirow{2}{*}{$\begin{array}{l}\text { Sample } \\
\text { Thickness } 2 / \\
\text { in. (mm) }\end{array}$} & \multirow{2}{*}{$\begin{array}{l}\text { Asphalt } \\
\text { Thickness } 2 / \\
\text { in. (mm) }\end{array}$} & \multirow{2}{*}{$\begin{array}{l}\text { Rate } \\
1 \mathrm{bs} / 100 \\
\text { sq.ft. }\end{array}$} & \multirow{2}{*}{$\mathrm{kg} / \mathrm{m}^{2}$} \\
\hline & $\begin{array}{l}\text { No. of } \\
\text { Plies } \\
\end{array}$ & Felts & & & & \\
\hline $\begin{array}{l}1-L \\
1-F\end{array}$ & 3 & Organic, Type 15 & $\begin{array}{l}.32(8.1) \\
.19(4.8)\end{array}$ & $\begin{array}{l}.04(1.0) \\
.02(0.5)\end{array}$ & $\begin{array}{l}21 \\
10\end{array}$ & $\begin{array}{l}(1.0) \\
(0.5)\end{array}$ \\
\hline $\begin{array}{l}2-L \\
2-F\end{array}$ & 4 & Organic, Type 15 & $\begin{array}{l}.38(9.7) \\
.34(8.6)\end{array}$ & $\begin{array}{l}.04(1.0) \\
.03(0.8)\end{array}$ & $\begin{array}{l}21 \\
16\end{array}$ & $\begin{array}{l}(1.0) \\
(0.8)\end{array}$ \\
\hline $\begin{array}{l}3-L \\
3-F\end{array}$ & 3 & Asbestos, Type 15 & $\begin{array}{l}.28(7.1) \\
.19(4.8)\end{array}$ & $\begin{array}{l}.05(1.3) \\
.03(0.8)\end{array}$ & $\begin{array}{l}26 \\
16\end{array}$ & $\begin{array}{l}(1.3) \\
(0.8)\end{array}$ \\
\hline $\begin{array}{l}4-L \\
4-F\end{array}$ & 4 & Asbestos, Type 15 & $\begin{array}{l}.38(9.7) \\
.26(6.6)\end{array}$ & $\begin{array}{ll}.05 & (1.3) \\
.03 & (0.8)\end{array}$ & $\begin{array}{l}26 \\
16\end{array}$ & $\begin{array}{l}(1.3) \\
(0.8)\end{array}$ \\
\hline $\begin{array}{l}5-L \\
5-F\end{array}$ & 3 & $\begin{array}{l}\text { Coated base sheet }+ \\
2 \text { Organic Type } 15\end{array}$ & $\begin{array}{l}.34(8.6) \\
.22(5.6)\end{array}$ & $\begin{array}{l}.05(1.3) \\
.02(0.5)\end{array}$ & $\begin{array}{l}26 \\
10\end{array}$ & $\begin{array}{l}(1.3) \\
(0.5)\end{array}$ \\
\hline $\begin{array}{l}6-L \\
6-F\end{array}$ & 4 & $\begin{array}{l}\text { Coated base sheet }+ \\
3 \text { Organic Type } 15\end{array}$ & $\begin{array}{l}.32(8.1) \\
.29(7.4)\end{array}$ & $\begin{array}{l}.04(1.0) \\
.02(0.5)\end{array}$ & $\begin{array}{l}21 \\
10\end{array}$ & $\begin{array}{l}(1.0) \\
(0.5)\end{array}$ \\
\hline $\begin{array}{l}7-L \\
7-F\end{array}$ & 2 & $\begin{array}{l}\text { Proprietary System } \\
\text { Heavyweight Asphalt } \\
\text { Saturated Felt }\end{array}$ & $\begin{array}{l}.27(6.9) \\
.24(6.1)\end{array}$ & $\begin{array}{l}.06(1.5) \\
.02(0.5)\end{array}$ & $\begin{array}{l}31 \\
10\end{array}$ & $\begin{array}{l}(1.5) \\
(0.5)\end{array}$ \\
\hline $\begin{array}{l}8-L \\
8-F\end{array}$ & 2 & $\begin{array}{l}\text { Proprietary System } \\
\text { Asphalt Saturated } \\
\text { and Coated Felt }\end{array}$ & $\begin{array}{l}.24(6.1) \\
.24(6.1)\end{array}$ & $\begin{array}{l}.04(1.0) \\
.03(0.8)\end{array}$ & $\begin{array}{l}21 \\
10\end{array}$ & $\begin{array}{l}(1.0) \\
(0.8)\end{array}$ \\
\hline $\begin{array}{l}9-L \\
9-F\end{array}$ & 2 & $\begin{array}{l}\text { Proprietary System } \\
\text { Asphalt-Impregnated } \\
\text { Glass Fiber Mat } \\
\text { (Felt) }\end{array}$ & $\begin{array}{l}.18(4.6) \\
.13(3.3)\end{array}$ & $\begin{array}{l}.04(1.0) \\
.04(1.0)\end{array}$ & $\begin{array}{l}21 \\
21\end{array}$ & $\begin{array}{l}(1.0) \\
(1.0)\end{array}$ \\
\hline
\end{tabular}

1/ $\mathrm{L}=$ laboratory-prepared samples, $\mathrm{F}=$ field-prepared samples 2/ Average of 3 measurements per specimen, 3 specimens per sample 


\begin{tabular}{|c|c|c|c|c|c|c|c|c|c|}
\hline \multirow{2}{*}{$\begin{array}{l}\text { Specimen } \\
\text { No. } 1 /\end{array}$} & \multirow{2}{*}{$\begin{array}{c}\text { Direction } \\
\text { of } \\
\text { Cut } \\
\end{array}$} & \multicolumn{2}{|c|}{$\begin{array}{c}\text { S } \\
\text { Breaking } \\
\text { Load }\end{array}$} & \multicolumn{2}{|c|}{\begin{tabular}{l}
\multicolumn{1}{c}{ M } \\
E1ongation \\
Modulus
\end{tabular}} & \multicolumn{2}{|c|}{$\begin{array}{c}\alpha \\
\text { Coefficient of } \\
\text { Thermal Expansion } \\
\text { (Linear) } \underline{3} /\end{array}$} & \multicolumn{2}{|c|}{$\begin{array}{l}\text { Thermal Shock } \\
\text { Resistance } \\
\text { Factor- }\end{array}$} \\
\hline & & & $\mathrm{kg} / \mathrm{cm}$ & $1 \mathrm{~b} /$ in. & $\mathrm{kg} / \mathrm{cm}$ & $\operatorname{per}^{\circ} \mathrm{F}$ & per ${ }^{\circ} \mathrm{C}$ & deg.F. & deg.C \\
\hline \multirow[t]{2}{*}{$1-\mathrm{L}$} & Longitudinal & 350 & (63) & $2.5 \times 10^{4}$ & $\left(0.45 \times 10^{4}\right)$ & $14 \times 10^{-6}$ & $\left(25 \times 10^{-6}\right)$ & 1000 & $(560)$ \\
\hline & Transverse & 190 & (34) & 1.3 & $(0.23)$ & 40 & $(72)$ & 370 & (210) \\
\hline \multirow{2}{*}{$1-F$} & $\mathrm{~L}$ & 380 & (68) & 3.0 & $(0.54)$ & 7 & (13) & 1850 & $(1060)$ \\
\hline & $\mathrm{T}$ & 180 & (32) & 1.5 & $(0.27)$ & 25 & (45) & 500 & $(280)$ \\
\hline \multirow{2}{*}{$2-L$} & $\mathrm{~L}$ & 390 & $(70)$ & 3.6 & $(0.64)$ & 15 & (27) & 720 & $(400)$ \\
\hline & $\mathrm{T}$ & 250 & (45) & 2.5 & $(0.45)$ & 34 & (61) & 460 & $(260)$ \\
\hline \multirow{2}{*}{$2-F$} & $\mathrm{~L}$ & 500 & (90) & 3.7 & $(0.66)$ & 12 & (22) & 1120 & $(620)$ \\
\hline & $\mathrm{T}$ & 250 & (45) & 2.3 & $(0.41)$ & 36 & (65) & 300 & (170) \\
\hline \multirow{2}{*}{$3-\mathrm{L}$} & $\mathrm{L}$ & 210 & (38) & 2.7 & $(0.48)$ & 14 & (25) & 550 & (310) \\
\hline & $\mathrm{T}$ & 140 & (25) & 1.5 & $(0.27)$ & 23 & (41) & 410 & (230) \\
\hline \multirow[t]{2}{*}{$3-F$} & $\mathrm{~L}$ & 270 & $(48)$ & 3.4 & $(0.61)$ & 9 & (16) & 880 & $(490)$ \\
\hline & $\mathrm{T}$ & 180 & (32) & 2.1 & $(0.38)$ & 18 & (32) & 460 & $(260)$ \\
\hline \multirow[t]{2}{*}{$4-L$} & $\mathrm{~L}$ & 230 & (41) & 3.3 & $(0.59)$ & 12 & (22) & 580 & $(320)$ \\
\hline & $\mathrm{T}$ & 200 & (36) & 2.7 & $(0.48)$ & 23 & (41) & 320 & $(180)$ \\
\hline \multirow[t]{2}{*}{$4-F$} & $\mathrm{~L}$ & 370 & $(66)$ & 5.0 & $(0.89)$ & 7 & (13) & 1045 & $(580)$ \\
\hline & $\mathrm{T}$ & 260 & (47) & 3.6 & $(0.64)$ & 17 & (31) & 430 & $(240)$ \\
\hline \multirow[t]{2}{*}{$5-L$} & $\mathrm{~L}$ & 230 & (41) & 3.3 & $(0.59)$ & 12 & (22) & 580 & (320) \\
\hline & $\mathrm{T}$ & 200 & (36) & 2.7 & $(0.48)$ & 23 & (41) & 320 & (180) \\
\hline \multirow[t]{2}{*}{$5-F$} & L & 310 & (56) & 3.3 & $(0.59)$ & 8 & (14) & 1250 & $(690)$ \\
\hline & $\mathrm{T}$ & 180 & (32) & 2.1 & $(0.38)$ & 16 & (29) & 540 & $(300)$ \\
\hline \multirow[t]{2}{*}{$6-L$} & $\mathrm{~L}$ & 480 & $(86)$ & 4.2 & $(0.75)$ & 8 & (14) & 1430 & $(790)$ \\
\hline & $\mathrm{T}$ & 260 & (47) & 1.4 & $(0.25$ & 37 & (67) & 410 & (230) \\
\hline \multirow[t]{2}{*}{$6-F$} & L & 470 & (84) & 4.4 & $(0.79)$ & 7 & (13) & 1500 & (830) \\
\hline & $\mathrm{T}$ & 230 & (41) & 2.6 & $(0.46)$ & 14 & (25) & 640 & $(360)$ \\
\hline \multirow[t]{2}{*}{ 7-L } & $\mathrm{L}$ & 370 & $(66)$ & 3.4 & $(0.61)$ & 13 & (23) & 840 & $(470)$ \\
\hline & $\mathrm{T}$ & 240 & (43) & 2.4 & $(0.43)$ & 25 & (45) & 380 & (210) \\
\hline \multirow[t]{2}{*}{$7-F$} & L & 350 & (63) & 3.4 & $(0.61)$ & 13 & (23) & 840 & $(470)$ \\
\hline & $\mathrm{T}$ & 230 & (41) & 2.2 & $(0.39)$ & 26 & (47) & 390 & (220) \\
\hline \multirow[t]{2}{*}{ 8-L } & $\mathrm{L}$ & 290 & (52) & 3.3 & $(0.59)$ & 17 & (31) & 520 & (290) \\
\hline & $\mathrm{T}$ & 200 & (36) & 2.3 & $(0.41)$ & 34 & (61) & 310 & $(170)$ \\
\hline \multirow[t]{2}{*}{$8-F$} & $\mathrm{~L}$ & 320 & (57) & 3.0 & $(0.54)$ & 15 & (27) & 710 & (390) \\
\hline & $\mathrm{T}$ & 160 & (29) & 1.8 & $(0.32)$ & 34 & (61) & 270 & (150) \\
\hline \multirow[t]{2}{*}{ 9-L } & L & 110 & $(20)$ & 1.7 & $(0.30)$ & 28 & (52) & 110 & $(60)$ \\
\hline & $\mathrm{T}$ & 80 & (14) & 2.3 & $(0.41)$ & 39 & (70) & 90 & (50) \\
\hline \multirow[t]{2}{*}{$9-F$} & $\mathrm{~L}$ & 120 & (22) & 1.5 & $(0.27)$ & 14 & (25) & 540 & $(300)$ \\
\hline & $\mathrm{T}$ & 90 & (16) & 2.2 & $(0.39)$ & 22 & (40) & 200 & (110) \\
\hline
\end{tabular}

$1 / \mathrm{L}=1$ aboratory-prepared samples. $\quad F=$ field-prepared samples.

2/ Average of three determinations at $0^{\circ} \mathrm{F}\left(-17.8^{\circ} \mathrm{C}\right)$

$3 /$ Average of two determinations, temperature range $+30^{\circ} \mathrm{F}$ to $-30^{\circ} \mathrm{F}\left(-1.1^{\circ} \mathrm{C}\right.$ to $\left.-34.4^{\circ} \mathrm{C}\right)$

4/ $\operatorname{TSRF}=\frac{\mathrm{S}}{\mathrm{MX} \alpha}$ 


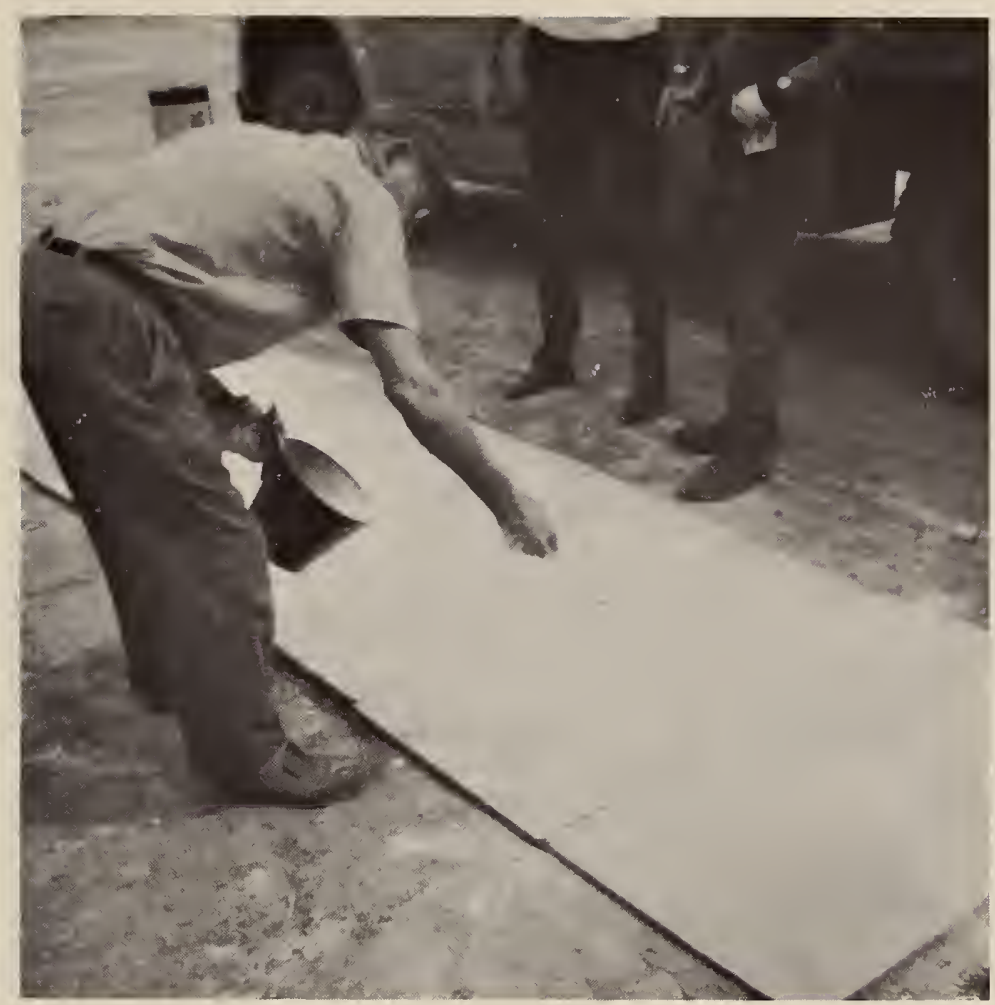

FIGURE 1. Coating of insulation boards with lime dust to prevent adhering of field samples.

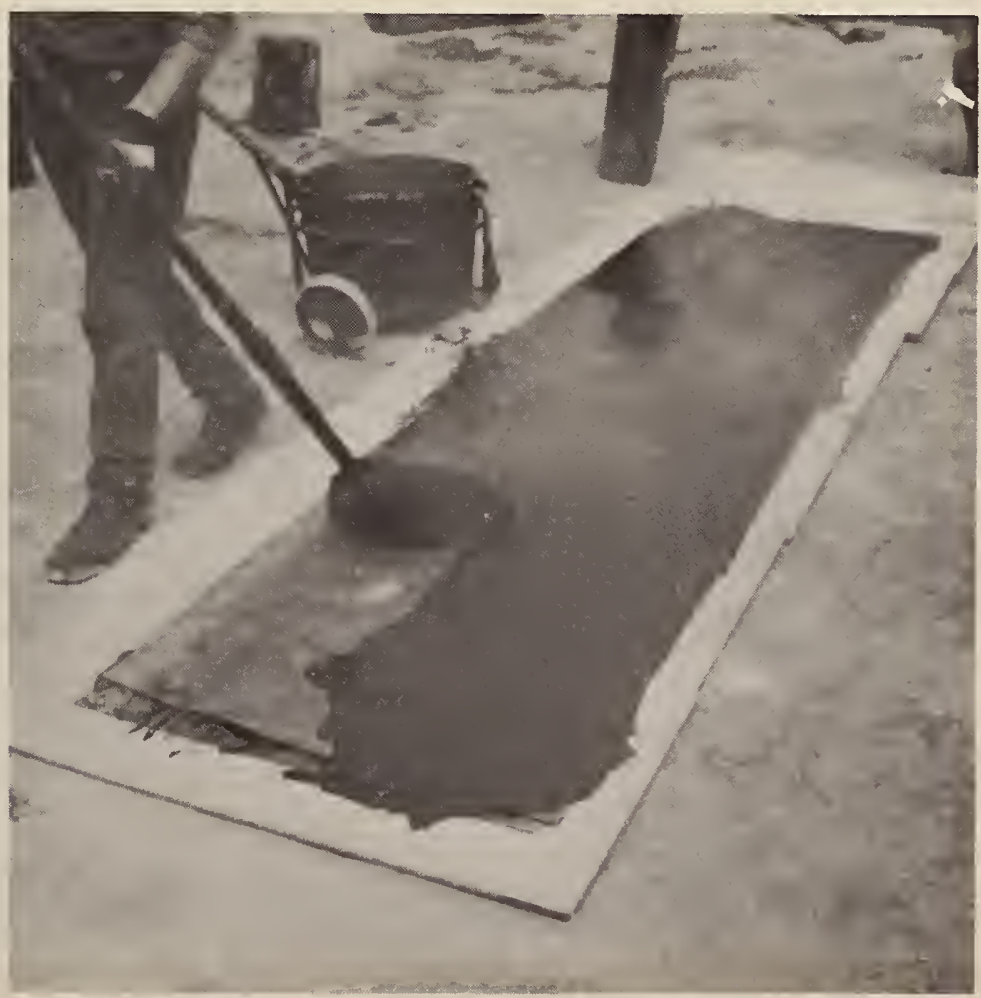

FIGURE 2. Application of hot asphalt to felt. 


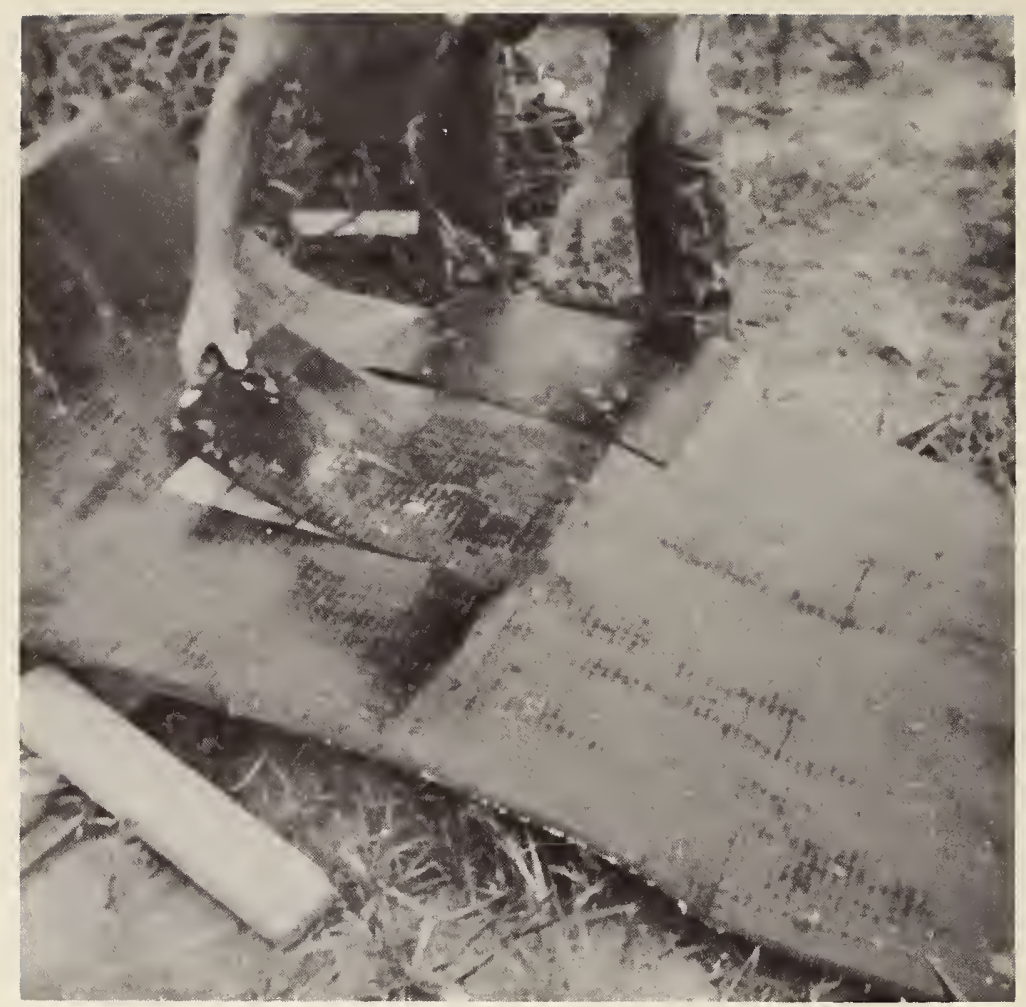

FIGURE 3. Removing of $2 \times 2$ foot cut-out from field prepared sample.

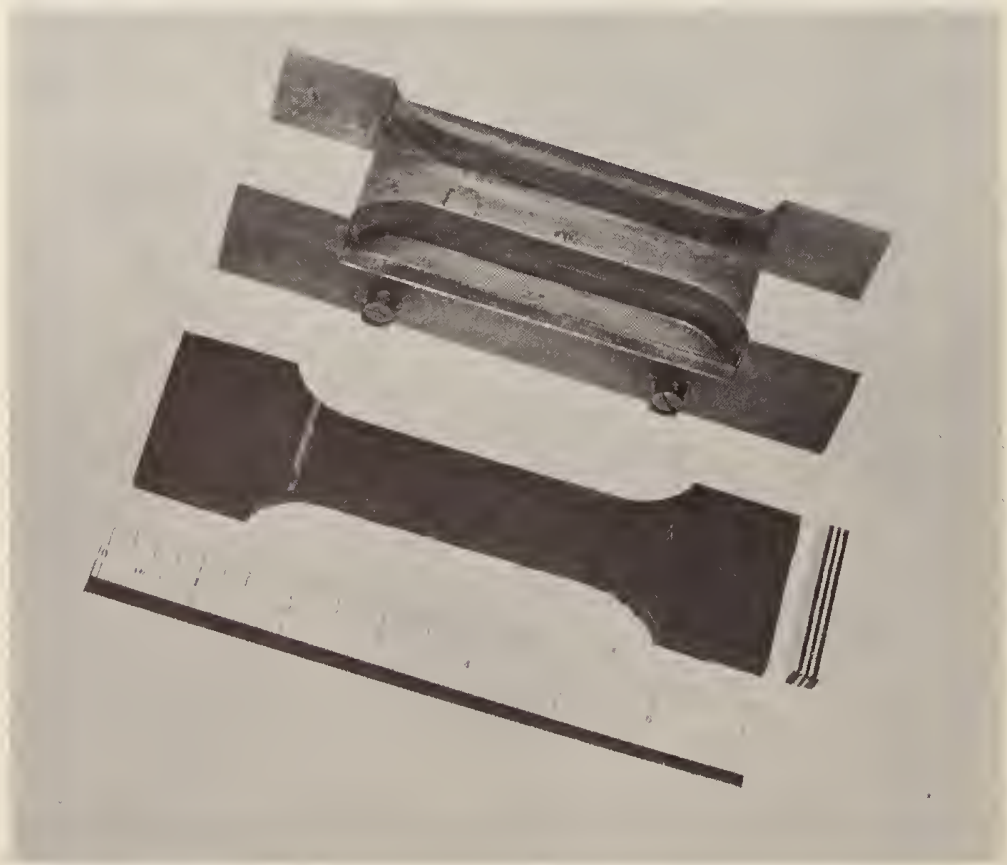

FIGURE 4. Cutting die, built-up roofing specimen and cross section of membrane. 


\section{TYPICAL LOAD ELONGATION CURVE}

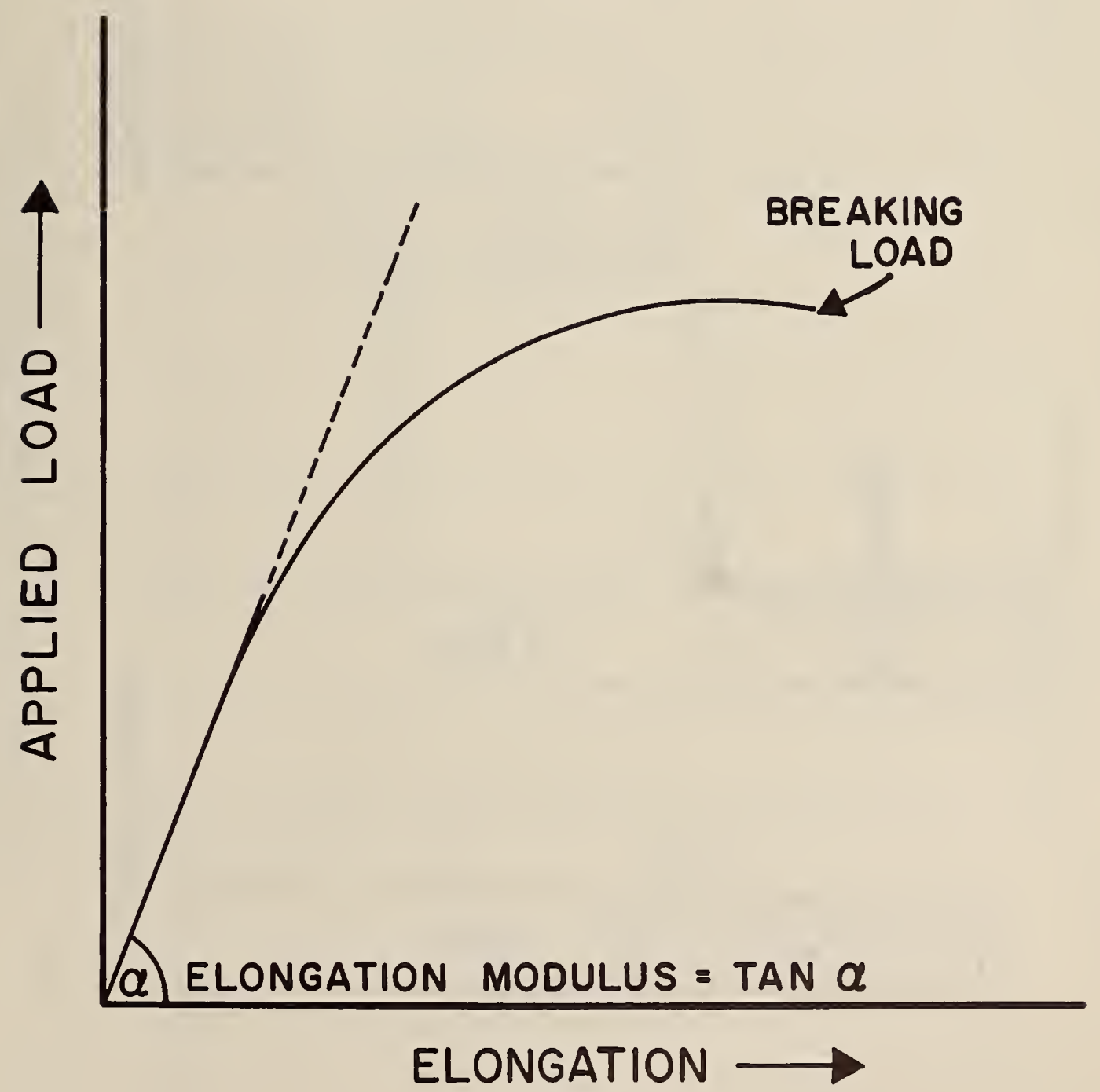

FIGURE 5. Typical tensile test load elongation curve illustrating the determinations of elongation modulus and breaking load. 


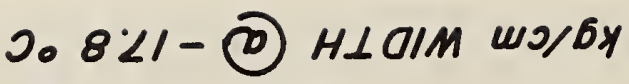
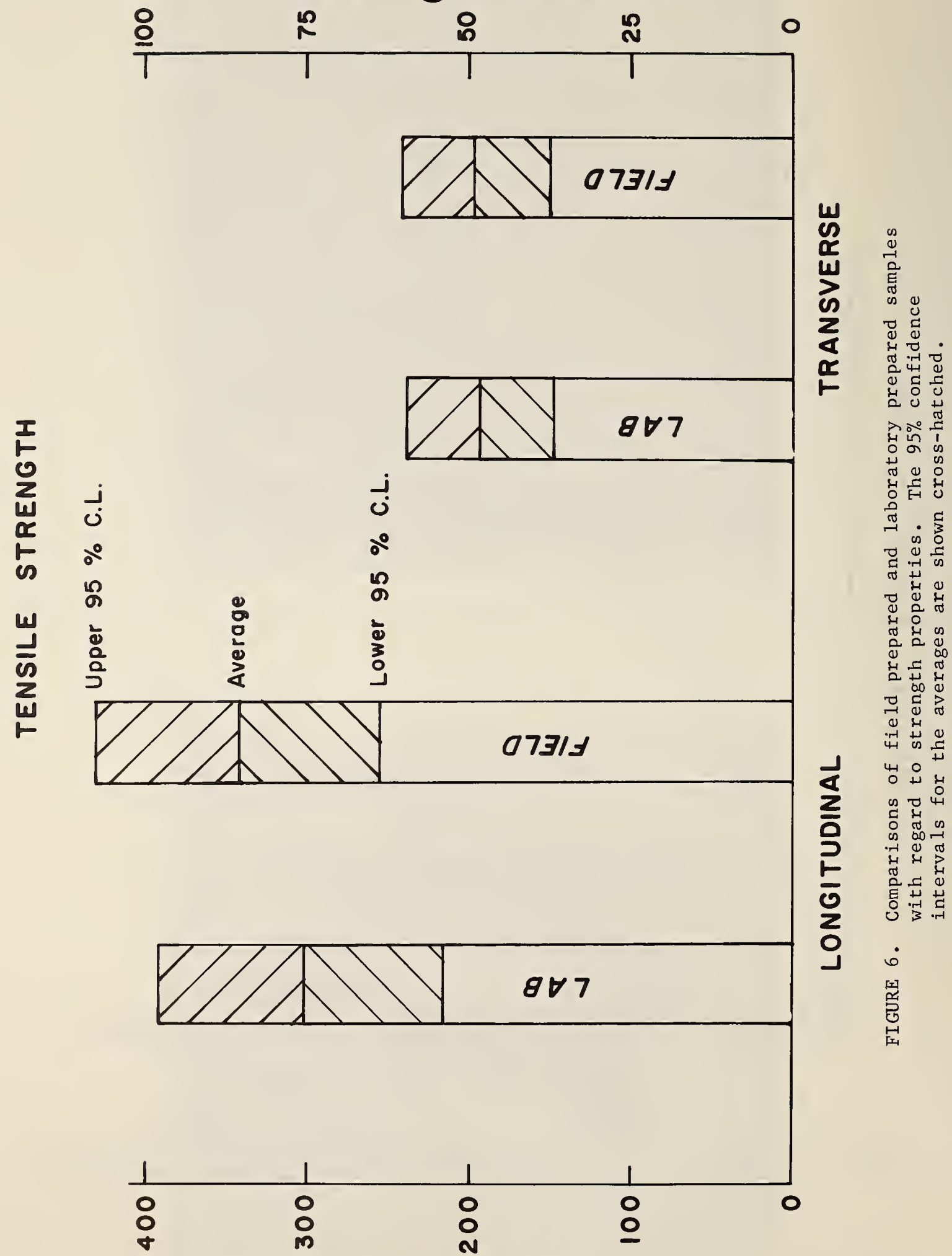

toO@ HLOIM NI/87 


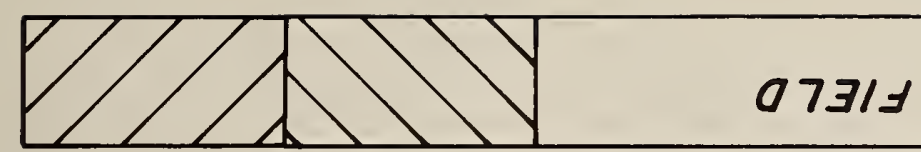

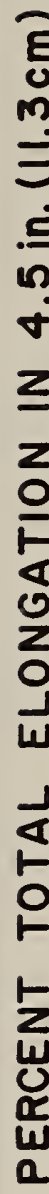

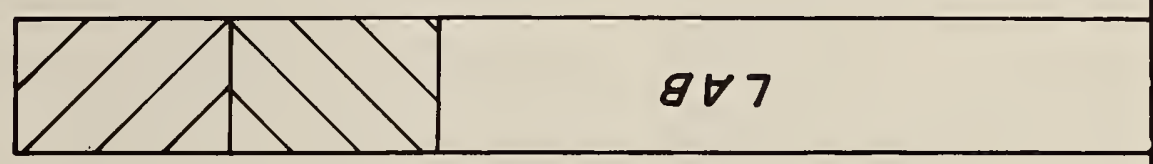

$2 \frac{j}{0} \int_{0}^{j}$

j.

- $\infty^{n}$

o

$<\infty \sigma$

$0^{\infty} \pm$

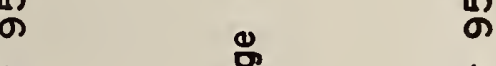

ต

군음

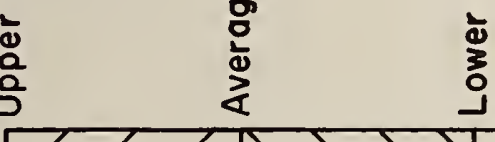

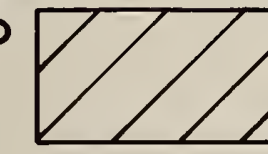

07311

w

$\sum_{\substack{\omega \\ \infty}}^{\infty}$

$\alpha$ व

a

F

ฮี

เุํำ

นูก

त्र० 1

0 \& in

स

मु मै

तै के

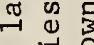

두

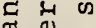

त

व के

¿ म्र

म

叫

o o o

起占密

○

$\rightarrow$ ᄃ

(1) 0

$1 \quad 40 \frac{2}{2}$

$\frac{2}{2}$

넝 오 서

का

ᄃ

雪 0

$\rightarrow-10$

我离

-

$\sigma$ ह

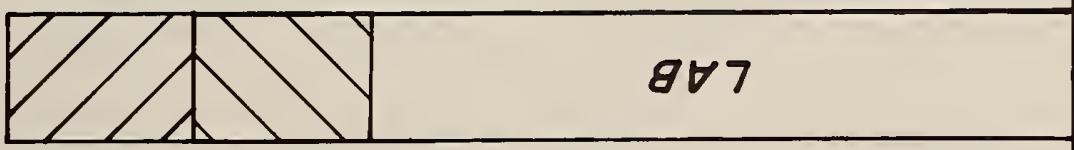

203.7

,

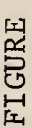

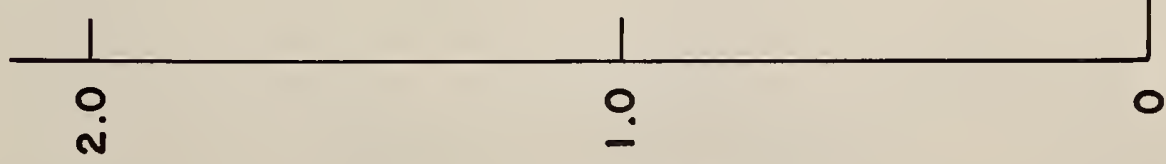

LNJJ4 $3 d$ 



\section{NBS TECHNICAL PUBLICATIONS}

\section{PERIODICALS}

JOURNAL OF RESEARCH reports National Bureau of Standards research and development in physics, mathematics, chemistry, and engineering. Comprehensive scientific papers give complete details of the work, including laboratory data, experimental procedures, and theoretical and mathematical analyses. Illustrated with photographs, drawings, and charts.

\section{Published in three sections, available separately:}

\section{- Physics and Chemistry}

Papers of interest primarily to scientists working in these fields. This section covers a broad range of physical and chemical research, with major emphasis on standards of physical measurement, fundamental constants, and properties of matter. Issued six times a year. Annual subscription: Domestic, $\$ 6.00$; foreign, $\$ 7.25^{*}$.

\section{Mathematical Sciences}

Studies and compilations designed mainly for the mathematician and theoretical physicist. Topics in mathematical statistics, theory of experiment design, numerical analysis, theoretical physics and chemistry, logical design and programming of computers and computer systems. Short numerical tables. Issued quarterly. Annual subscription: Domestic, $\$ 2.25$; foreign, $\$ 2.75^{*}$.

\section{- Engineering and Instrumentation}

Reporting results of interest chiefly to the engineer and the applied scientist. This section includes many of the new developments in instrumentation resulting from the Bureau's work in physical measurement, data processing, and development of test methods. It will also cover some of the work in acoustics, applied mechanics, building research, and cryogenic engineering. Issued quarterly. Annual subscription: Domestic, $\$ 2.75$; foreign, $\$ 3.50^{*}$.

\section{TECHNICAL NEWS BULLETIN}

The best single source of information concerning the Bureau's research, developmental, cooperative and publication activities, this monthly publication is designed for the industry-oriented individual whose daily work involves intimate contact with science and technology-for engineers, chemists, physicists, research managers, product-development managers, and company executives. Annual subscription: Domestic, $\$ 3.00$; foreign, $\$ 4.00^{*}$.

\section{NONPERIODICALS}

Applied Mathematics Series. tables, manuals, and studies.

Building Science Series. Research results, test methods, and performance criteria of building materials, components, systems, and structures.

Handbooks. Recommended codes of engineering and industrial practice (including safety codes) developed in cooperation with interested industries, professional organizations, and regulatory bodies.

Special Publications. Proceedings of NBS conferences, bibliographies, annual reports, wall charts, pamphlets, etc.

Monographs. Major contributions to the technical literature on various subjects related to the Bureau's scientific and technical activities.

National Standard Reference Data Series. NSRDS provides quantitative data on the physical and chemical properties of materials, compiled from the world's literature and critically evaluated.

Product Standards. Provide requirements for sizes, types, quality and methods for testing various industrial products. These standards are developed cooperatively with interested Government and industry groups and provide the basis for common understanding of product characteristics for both buyers and sellers. Their use is voluntary.

Technical Notes. This series consists of communications and reports (covering both other agency and NBS-sponsored work) of limited or transitory interest.

Federal Information Processing Standards Publications. This series is the official publication within the Federal Government for information on standards adopted and promulgated under the Public Law 89-306, and Bureau of the Budget Circular A-86 entitled, Standardization of Data Elements and Codes in Data Systems.

\section{CLEARINGHOUSE}

The Clearinghouse for Federal Scientific and Technical Information, operated by NBS, supplies unclassified information related to Governmentgenerated science and technology in defense, space, atomic energy, and other national programs. For further information on Clearinghouse services, write:

Clearinghouse

U.S. Department of Commerce

Springfield, Virginia 22151
Superintendent of Documents

Government Printing Office

Washington, D.C. 20402 
U.S. DEPARTMENT OF COMMERCE
WASHINGTON, D.C. 20230

U.S. DEPARTMENT OF COMMERCE
WASHINGTON, D.C. 20230

OFFICIAL BUSINESS

(2)

OFFICIAL BUSINESS

OFFICIAL BUSINESS 